\title{
The Role of Innovative Bank Products on Customer Perception Influencing Accounting Procedures in Kurdistan
}

\section{Barham Khalid Hassan}

Accounting Department, College of Public Administration and Natural Resource Management, Charmo University, Chamchamal, Kurdistan Region, Iraq.

E-mail: Barham.khalid@charmouniversity.org

\begin{abstract}
Ali Omer Mohammed
Kurdish Department, College of Education, Garmian University, Kalar, Kurdistan Region, Iraq. E-mail: Ali.omer@garmian.edu.krd
\end{abstract}

\section{Raqeeb Abdullah Omer}

Accounting Department, College of Erbil Administration Technical, Erbil Polytechnic University, Erbil, Kurdistan Region, Iraq.

E-mail: Raqeeb.omer@epu.edu.iq

\begin{abstract}
:
This study sought to find the role of innovative banking products on customer perception influencing accounting procedures in Kurdistan. The Innovative banking product was embraced as an independent variable through (transactional costs, innovation, and accessibility) and customer perception as a dependent variable. Lack of understanding of customer perception and accounting procedures is proving to be the main problem of the acceptance of products as it is the source of economic benefit in the Kurdistan financial sector. Pearson correlation tests were carried out to assess the relationship between the independent variables (Transaction costs, accessibility and innovation) and the dependent variable of Customer perceptions. Statistical package for the social sciences program (SPSS 20) was used for data analysis and presentation. Results indicated that all variables had a positive relationship with customer perceptions. The study recommended that the banks need to understand the risks associated with innovation in line with the accounting procedures to understand customer's perception before developing and rolling out new products. Customers view products and services differently, therefore there is need to improve on customer relations, customer education and awareness and customer loyalty.
\end{abstract}

Keywords: Innovation, Customer Satisfaction, Transactional Costs, Accessibility and Finance. 334 


\section{INTRODUCTION :}

The collapse of the economy affected the banking sector and its relationship with customers, due to the liquidity problems which the banks faced during 2014. During this period, banks started introducing innovative banking products that were cost effective, secure, economic environment and profit as they were trying to survive in the harsh business environment. In that economic crisis, the banks didn't even have time to go through the product introduction process of thoughtful collaboration, deliberate testing, customer input, and objective analysis. It would have been more costly to go through the process, there were mainly concerned to know if the product will bring revenue and make profit. This however, led to the customers losing confidence in the banking sector. After the economy stabilized, the banking sector had to come up with innovate financial products so as to regain customer confidence and customer loyalty and become financially stable and competitive. Deposits from clients are considered to be a financial source for banks; therefore the customer's satisfaction can be viewed as the main key to the function, stability and operation of a bank. The most successful banks are the ones who are able to connect with their customers and provide value-added facilities that are consistent with the essentials and requests of their customers.

The survival of an organization is the market place is determined by successfully introducing and developing acceptable and attractive innovative financial products. In the process of meeting customer needs, we have seen the innovation of different types of saving and current accounts and technology products that were not possible in the past years. These products have contributed to the growth in the banking industry. Kurdistan has been experiencing an increased use and development of mobile smartphone, which has led to the demand of smart technological banking in the country. This smart technological banking has increased services and value to consumer's financial transactions (Ameen \& Willis, 2018; Sultan, Hassan, \& Noor, 2016; Sultan et al., 2018). These increased developments of new product and services offering in the banking industry gives us a picture that banks are coming up with more innovative products not which were not possible. Several banks in Kurdistan have invested heavily in developing financial systems and applications which are easily accessible and usable to customers so as to increase their gratification, but the rate at which people are using these facilities is low (CihanBank, 2019). However, with increased competition in new product and services offering, there still remain a great part of the economy unbanked and a number of customers are not adopting the products. Current banking products seem to focus on adults who receive a regular salary because Kurdistan remains a cash-based economy. It is reported that over $70 \%$ of clients who generate a disliking of financial products is due to dissatisfaction of the services. Therefore, the main duty of the bank is not just to develop and build financial systems and 
applications to gain and attract many customers but to maintain and retain them. Clients are maintained and retained by fulfilling their desires and needs.

Consumer Fulfillment is the key to the achievement of any financial institution therefore the understanding of customer's perception of banking products is vital to banks. Despite efforts by banks in developing better financial products, these products remain underused by bank customers and little or no consideration has been given to how bank customers perceive financial innovation. Innovative financial products can only gain significance if the adoption by the customers is maintained. Therefore, this study sought to find how innovative banking product and services are perceived by customers and its influence on accounting procedures. The objectives of the study are to find drivers of, and barriers to the usage of banking products and services by customers, to understand customer insight towards innovative financial products and service, to understand which factors all customers agree on, even though they have different taste and views, to discover that the customers think about advanced financial services and to help improve quick adoption of financially innovative products by customers. The research will solve the following questions, attitudes of customers towards banking products and services, why should a bank introduce a new product and what drives the acceptances of banking products?

\section{THEORITICAL REVIEW}

Every innovative banking product has to be tested, analyzed and proved in the market for it to achieve sustainable growth and acceptability by the target population. The failure of an innovation causes a negative effect on the organization whilst its success brings about a favorable result. The heart and mind of customers is very important to satisfy whether the innovative product will survive/fail in the market. Therefore, understanding customer perception, innovation and the risk in innovative financial systems to customers are important factors in the banking sectors. According to Baker (2002), he suggests they are other factors that banks consider in financial innovation besides the NDP, which are economic pressures to reduce costs and improve efficiency, a rise in competition, reduction in the product lifetime, improvement of value, increased banks regulations, the need for continuous development in the industry and society, demand on improved social expectations and accountability, changes in the market and demographic, increasing customer expectations in quality and service, the need to copy with the latest technological improvements and advancements in the market and economy. 
The increased competition in the banking sector has promoted banks to invest in technological innovations to attract more customers, reduce transactional costs, and create a more convenient way of banking for their current clients. Joseph and Stone (2003) noted in order to improve and maintain customer loyalty and increase market share, user friendly banking systems should be installed. The China Banking Regulatory Commission 2009 (CBRC) stated that it would change and monitor the existing laws in the banking industry on financial development, so has to build a sound legal environment. Banks should develop innovative financial products under the standard of reasonable rivalry, other than the utilization of exclusive data, rights and licenses. Banks will avoid hostile to aggressive practices, forceful valuing rivalry and price fixing. Customer satisfaction is expressed by the customer's judgment on a product or a service after he's or her consumption meets expectation. Satisfied customers can share their experience with the products to other potential customer, which can be an easy way to market and provide positive communication and assurance (Solomon RM, 2009). However dissatisfied spread a negative message to others which will create a bad image of the products and services. Studies by (Mazzucato and Semieniuk 2017) on financial and accounting innovations, suggests that innovation on new products is centered on meeting the desires of the customer and also the desires of the company in improving its financial targets. These targets can only be achieved when proper accounting procedures are set up in line the innovations to meet the expectations. These types of accounting procedures include bank reconciliation, issuing bills to clients, creation and payment of invoice to supplies and among others. Every innovation has got risks which will affect in a good or bad way the presentation and accounting standards of an organization, therefore innovation can not only be based on consumer perceptions but also the accounting procedures of the business. Many customers complain about unorganized personal financial transaction and reconciliation from the banks. Innovation can help the banks create well-presented accounting procedures to satisfy customer's desires. Thus from the above obseravtion we should accept that;

H1 A constructive and substantial association exits between customer perception and innovation.

\section{Accessibility :}

The innovativate products should be easily understood and accessible by customers, thus understaind how an innovation is adpoted and felt by a customer is important. Studies by Lassar et al. (2004), proposed that utilization of innovation based framework relies on the customers feeling and demeanor towards it and that level of purchasers' advancements matters in adjusting and using e- 
banking products and services. The findings were that for consumers to be well benefited, banking products should be organized according to the characteristics of customer's needs. Rogers (2003; $\mathrm{p}$. 177), views adoption as an assessment of "full use of an innovation as the best course of action available" and denial is a result "not to adopt an innovation". He's four main components of the diffusion of Innovations are invention, channels of communication, phase, and social system. Innovation is a thought, practice, or task that is seen as new by an individual (Rogers, 2003, p. 12). Vulnerability influences the reception of advancements which is made by innovation consequences. "Consequences are the changes that occur in customers or a social system as a result of the adoption or rejection of an innovation". Communication is "a process of creating and sharing information with one another reaching a mutual agreement" with these elements, innovation, participants of adoption, creates a communication channel. Time is a process when clients access the product to form attitude on whether to accept or refuse the innovation. The social system is defined as "a set of interrelated units engaged in joint problem solving to accomplish a common goal" (Rogers 2003).

Banks can create a very attracting innovative product but adoption is a different thing. Rogers (1995), five important factors that affect adoption decisions are: Customers perceived usefulness, Portability, Compatibility, Observability and Trainability.Customer perceived usefulness explains the degree to which financial innovative products are easy to operate and understand. Black et al. (2001) indicated that if customers perceive that the innovation is complicated, time is taken before it is accepted therefore financial institutions have to create other ways of winning clients. Therefore customer perception is an important tool on products adoption (Kent et al. 2008). Rogers (2003, p. 15) clarifies that 'compatibility is the extent to which beliefs, ethics and practices of the target market or potential adopters are consistent with innovation. Studies by Gerrard and Cunningham (2003) on factors affecting e-banking adoption, he recognized different factors which has an effect adoption rate and compatibility was conceded an influence.

In Eriksson et al. 2008 studies indicated that for an innovation to be conceded portable and acessible, it should be better than the previous products. In banking we will say that the product should be more users friendly. In reviewing studies by (Taylor \& Todd, 1995; Lu et al., 2005) indicate that innovative banking products that create a convenient and portable way of banking have a positive effect on acceptance / adoption of the products. Thus, from the view of this background it is safe for us to say that;

H2 A constructive and substantial association exits between customer perception and Accessibility. 


\section{Transcational costs:}

Laukkanen and Kiviniemi (2010) showed that the information banks provide to the customers on new products create a progressive consequence on the clients' acceptance of financial innovation. Limited ways of distributing information about newly innovated financial products and the transactional costs limit the uptake of the new products in the financial sector. Lee and Chung (2009) empirical results indicated that the amount and quality of information released to the customers on transcational costs and other related things by the banks has a positive impact on the adoption of any innovative banking product. Suganthi et al (2001) also added that for new techonological innovations to be accepted, it most be reasonably priced less compared to the current exits innovations. Studies by Singh and Padmanabhan (2004) indicated that low transactional fee, reliability, convenience and other factors influence and affects consumer perceptions.Their observation showed $81 \%$ of respondents quickly adopt internet banking because of the charges and information provided. Other researchers supported this finding, Abor (2004) found that technological innovation helps reduces time spent on banking transactions and it is less costly with $80.4 \%$ of customers are agreeing.

However, Beckett et al. (2000) said that clients stay faithful to the same financial Institution paying little respect to have unfavorable perspectives about the administration. There may be a few explanations behind clients to neglect to see the distinction between different administration, a shopper may be propelled by the comfort, lastly clients see changing banks include high exchanging expenses as far as endeavors and potential penance (Jamal and Naser, 2002). Conversely, althoughin spite of the fact that it's a typical reason that fulfilled clients buy over and over. The banking sector part is an excellent case of an industry where Customer Satisfaction and repeat purchase are not emphatically related. The Bank of America proudly declared in its 2003 profit report that one of its client highlights was an increment in the most elevated amount of satisfaction of $14 \%$ ( Bank of America, 2003). This was truly amazing yet the bank was looted off all the credit when more profound study uncovered that this just spoke to $1.5 \mathrm{mn}$ of its $28 \mathrm{mn}$ clients (5.3\% of customers). Satisfaction of the staying $94.5 \%$ clients can't be followed. Choice (2002), further found that in Australia, the Big Four banks that stand out have 23-32\% of their clients disappointed with their bank. This shows that achievement results from proactive business sector understanding, instead of from falteringly taking after the proposals of key clients (Johne and Snelson, 1990). However, these four banks are in the main six open organizations in Australia with record benefits surpassing \$3bn between them. It creates the impression that Customer Satisfaction is redundant for rehash faithfulness. In veiw of the above argument we can say that; 
H3 A constructive and substantial association exits between customer perception and transactional costs.

\section{Method:}

A quantitative analysis with the use of questionnaire was adopted. Purposive sampling technique was utilized in data collection. Statistical package for the social sciences program (SPSS 20) was used for data analysis. The target population will be banking clients of banks in Kurdistan region in the area who use innovative banking products and services. The study employed closed ended questionnaire, for which 400 questionnaires were distributed and 390 were completed and returned. Various statistical tests which included descriptive statistics, Pearson correlation, and chi-s Adoption behavior of customer square tests were carried out to assess the relationship between our variables.

\section{Measure:}

The research based its instruments on previously established scales from various literature reviews on customer perceptions and financial innovation. A likert type 5 point scale with strongly diagree to strongly agree was used. The variables on the questionary were developed as follows; innovation was measured using a seven item scale developed by (musiime and bayaki 2010) with an example item of "In my opinion, the uses of innovative banking products (Internet banking/mobile banking ATM, etc.) services are economical". Customer perception used a seven item scale by (wu et al 2006 and Cohen et al 2006), sample item being "banking innovative products are very convenient". Accessibility variable used a seven item scale by (jannutual 2010), example item is "Innovative banking products are secure and my privacy can only be accessed by my authority." Transcational costs used a 7 item scale by (Anami 2010, Cohen et al 2006), example item is "I use innovative products to avoid extra costs inquired when transacting in the bank". To measure the drives of banking product usage, a six item scale developed by (schiffiman and kanuk 2009) was used. Other variables used were demographic for age and gender to analysis the uptake rate of each age group and gender. 


\section{Results :}

\section{Demographic Statistics}

Table 1 Summary demographic Statistics

\begin{tabular}{llllll}
\hline Variables & characterictis & Frequency & Percentage \% & Mean & Standard deviation \\
\hline Gender & Male & 171 & 43.8 & 1.5 & 0.497 \\
& Female & 219 & 56.2 & & \\
& & 390 & 100 & & \\
Age & Under 25 & & & & \\
& 26-35 years & 24 & 6.2 & 2.62 & 0.965 \\
& $36-50$ years & 189 & 48.5 & & \\
Total & 51-65 years & 39 & 29.2 & & \\
& Over 65 years & 24 & 6.2 & & \\
& & 390 & 100 & & \\
\hline
\end{tabular}

According to Schiffiman and kanuk (2009), states that innovative products are easily and quickly adopted by young people. Therefore the table 1 above can be proved to be reliable and effective has it shows that $48.5 \%$ of ages 26-35 years were the most frequent respondents and under 25 with $6.2 \%$. Those between 36-45 years of age accounted for 29.2\%, ages of 51-65 and over 65 accounted for $10 \%$ and $6.2 \%$ respectively. Females use innovative products than Male with $56.2 \%$ and $43.8 \%$ respectively. The mean for gender was 1.56 and standard deviation of 0.497 whlist age had a mean of 2.62 and a standard deviation of 0.965 . The results were from several banks mainly North bank, Central bank of Iraq, International development bank, Audi Bank, Harem Sulaymaniyah bank, Baban bank and RT bank. 
Table 2 Factor loading results

\begin{tabular}{|l|l|l|l|l|}
\hline Variable & $\begin{array}{l}\text { No of } \\
\text { items }\end{array}$ & Accepted & KMO & Bartlett's \\
Significant
\end{tabular}

\section{Source: Survey data}

Table 2 shows the factor loading results with ranges from 0.670-0.837 indicating good and reliable results for analysis. The moderate level recommended for cut off with Kaiser Meyer Oikin (KMO) is 0.5; however some scholars highly recommend a cut off point of 0.7 (pallat, 2011, nunnall, 1978). Due to the nature and purpose of the study items above the moderate cut off point of 0.5 are mainainted as good and relaible for analysis. All our variables were satisfactory with an adequacy sample of above (0.5) and significant Bartlett's test of $(\mathrm{p}<0.01)$.

\section{Correlation Marix}

Table 3 Correlations Marix

\begin{tabular}{lllll}
\hline & Perception & Innovation & Accessibility & $\begin{array}{l}\text { Transcational } \\
\text { costs }\end{array}$ \\
\hline Perception & 1 & & & \\
Innovation & 0.565 & 1 & & \\
Accessibility & 0.451 & 0.497 & 1 & \\
Transcational costs & 0.374 & 0.325 & 0.320 & 1
\end{tabular}

$* * *$ Correlation is significant at the level (2-tailed)

Table 3 results show a constructive correlation between innovation and customer perception exits with a Pearson correlation of $\left(0.565^{* *}\right)$ and an influence of independent variable on dependent variable is also shown with statistically substantial influence of (sig=0.001) less than (0.05).A constructive correlation between Accessibility and customer perception exits with a Pearson 
correlation of $\left(0.451^{* *}\right)$ and an influence of independent variable on dependent variable is also shown with statistically substantial influence of (sig=0.001) less than (0.05).A constructive correlation between Transactional costs and customer perception exits with a Pearson correlation of $(0.374 * *)$ and an influence of independent variable on dependent variable is also shown with statistically substantial influence of (sig=0.001) less than (0.05).

Table 4 Relationship between Customer Perceptions and the Independent variables

\begin{tabular}{|l|l|l|l|l|l|l|l|}
\hline $\begin{array}{l}\text { Independent } \\
\text { variables }\end{array}$ & $\mathbf{R}$ & $\begin{array}{l}\mathbf{R} \\
\text { Squared }\end{array}$ & $\begin{array}{l}\text { Adjusted } \\
\mathbf{R}\end{array}$ & F static & T test & $\begin{array}{l}\text { Beta } \\
\text { value }\end{array}$ & Sig \\
\hline Accessibility & 0.451 & 0.204 & 0.202 & 99.268 & 9.963 & 0.347 & 0.000 \\
\hline Innovation & 0.565 & 0.319 & 0.318 & 182.061 & 13.493 & 0.342 & 0.000 \\
\hline $\begin{array}{l}\text { Transactional } \\
\text { Costs }\end{array}$ & 0.374 & 0.140 & 0.138 & 63.200 & 7.950 & 0.272 & 0.000 \\
\hline
\end{tabular}

\section{Raw Data}

The above results in table 4 of our hypothesis indicate that After testing our hypothesis a positive correlation of $(\mathrm{R}=0.451)$ exits with an influence of the independent variable (Accessibility) on the dependent variable (customer perception), which is a statistically substantial influence, where F value reached (182.061) at significant level of ( $\mathrm{Sig}=0.000)$ which is less than (0.05), and from our hypothesis, it is accepted. It can be said that Accessibility has a great role in affecting how customers view innovated financial products which will greatly influence the accounting procedures. A positive correlation of $(\mathrm{R}=0.565)$ exits with an influence of the independent variable (innovation) on the dependent variable (customer perception), which is a statistically substantial influence, where F value reached (217.067) at significant level of $(\mathrm{Sig}=0.000)$ which is less than (0.05), and from our hypothesis, it is accepted. It can be said that innovation has a great role in affecting how customers view innovated financial products which will greatly influence the accounting procedures. A positive correlation of $(\mathrm{R}=0.374)$ exits with an influence of the independent variable (transactional costs) on the dependent variable (customer perception), which is a statistically substantial influence, where $\mathrm{F}$ value reached (63.200) at significant level of (Sig=0.000) which is less than (0.05), and from our hypothesis, it is accepted. It can be said that transactional costs have a great role in affecting how customers view innovated financial products which will significantly influence the accounting procedures. 


\section{Drivers of Banking Product Usage :}

The respondents indicated that all the factors on drivers of the usage of innovative products were important. In all cases, they had a $54.6 \%$ rate of importance. The features used and decisions were convenient, reliability, security, flexibility, saving of time and easy to use.

The table below shows the results:

Table 4 Drivers of Banking Product Usage

\begin{tabular}{|l|l|l|l|l|l|l|}
\hline & \multicolumn{6}{|c|}{ Responses Set (In percentage) } \\
\cline { 2 - 7 } & $\begin{array}{l}\text { Not } \\
\text { important }\end{array}$ & $\begin{array}{l}\text { Somewhat } \\
\text { important }\end{array}$ & Important & $\begin{array}{l}\text { Very } \\
\text { important }\end{array}$ & Mean & SQDV \\
\hline Convenience & 8.5 & 20.0 & 54.6 & 16.9 & 2.80 & 0.818 \\
\hline Reliability & 5.4 & 18.5 & 43.8 & 32.3 & 3.03 & 0.851 \\
\hline Security & 10 & 13.8 & 31.5 & 44.6 & 3.11 & 0.988 \\
\hline Flexibility & 10 & 17.7 & 35.4 & 36.9 & 2.99 & 0.974 \\
\hline Time Saving & 8.5 & 10.0 & 36.9 & 44.6 & 3.18 & 0.925 \\
\hline Ease of Use & 9.2 & 9.2 & 37.7 & 43.8 & 3.16 & 0.936 \\
\hline
\end{tabular}

\section{Adoption behavior and attitude of customers :}

The respondents were asked if they have adopted innovative banking products. The results indicated that $52.3 \%$ had adopted the innovative banking products whilst $47.7 \%$ have not yet. The results on adoption showed that $89.2 \%$ have positively/ are willing to adopt the products and $10.8 \%$ not yet. This result proves that young people and middle working class adopt innovative products quickly and have a positive mindset on the use of technology. 


\section{Discussion :}

The aim of the study was to find the role of innovative banking products on customer perception influencing accounting procedures in Kurdistan. The results showed that Innovative banking products through (accessibility, transactional costs, innovation) have a postive effect on customer perceptions influencing accounting procedures with positve correlation results on all the variables. These results are supported by the studies of singh and padamanabhan (2004), which indicated that for quick adoption of innvovated banking products, low transcational costs and easily understood softwares should be considered. Hayikader et al (2016), suggets that data information on clients and mobile internet Banking app usage can assists banks in designing systems and accounting procedures which can provide adequate security for future development of innovative banking products.

Oluwafeni et al (2019), on the study of forensic analysis of the mobile banking applications in Nigeria, his results suggestion that security and accounting procedures and systems should be considered when developing mobile application because it can be prom to hacking. This study matches with the results of our study which suggest that Innovative banking products through (accessibility, transactional costs, and innovation) helps the business in creating good and properly set accounting procedures with the understanding of customers' desires and needs thereby increasing profitability in the long run and reducing risks and frauds associated with innovation. Customer satisfaction is the key to any success of the bank, therefore banks should be able to build good customer relationships so that any financial innovation it has will bring out the heart and the mind of the customer.

The results from our study shows that banks in Kurdistan Region continue to create more innovative banking products with the young people in mind because they are quick to adopt but should also increase public awareness and education on the products. This is also shown in the studies of schiffiman and kankuk (2009), where his results showed that innovativate products are easily and quilcky adopted by young people.

\section{Conclusion:}

An innovative banking product through accessibility has shown that customers require bills (accounting procedure) they can easily access and understand and be able to communicate with the issuing department without any problems freely. Customer's views mean a lot to the banking sector. 
Privacy should be assured to the customers for them to give unbiased suggestion. The changes in technological innovations are making people to be up to date with the latest news and feeling the need to learn more. Therefore with this development banks should improve on infrastructure development and get up to date equipment and make life easy for the customers. The banks were not able to provide 24/7 services to customers because of a lack of developed infrastructure.

The study had various limations, although customers' views are regarded as important in developing innovative banking products, to some extent culture difference and type of bank plays an important in what the bank should develop. Therefore, this study only helps banks in a certain caterogy (commerical banks) and with certain operational systems. A study is needed to focus on offshore banks which actually look for higher or top class clients or have recommended clients base to join them. 


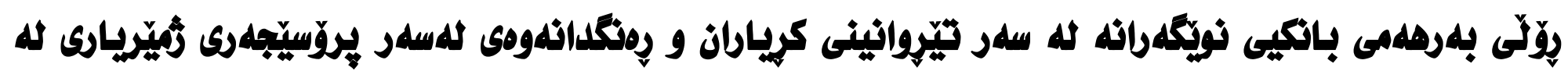 كورداستخاز}

$$
\begin{aligned}
& \text { بله رههم خاليل حسن }
\end{aligned}
$$

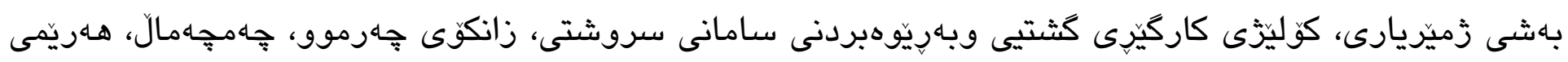

$$
\begin{aligned}
& \text { كوردستان، عيّراق. } \\
& \text { Barham.khalid@charmouniversity.org ئيمهيل: } \\
& \text { على عمر محمدل }
\end{aligned}
$$

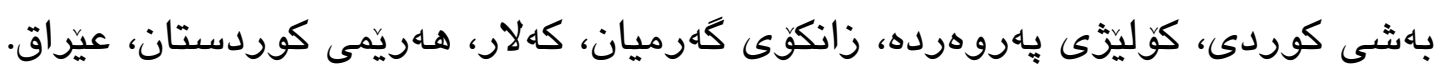

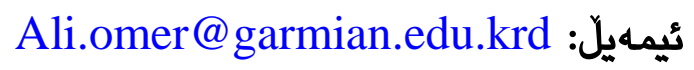

$$
\begin{aligned}
& \text { روقيب عبدلله عمر }
\end{aligned}
$$

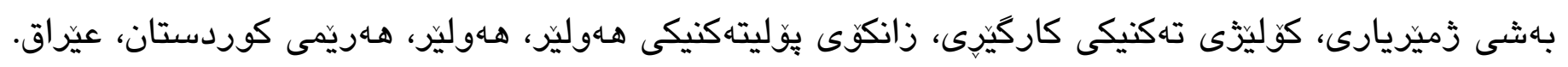

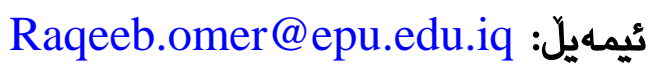




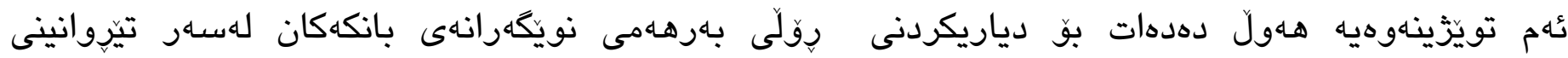

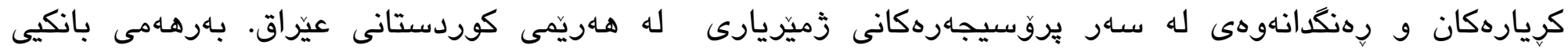

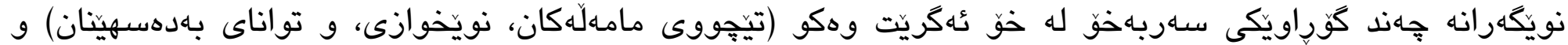

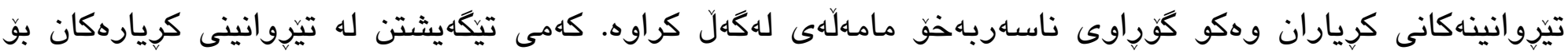

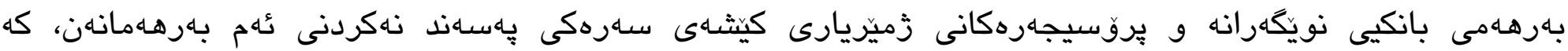

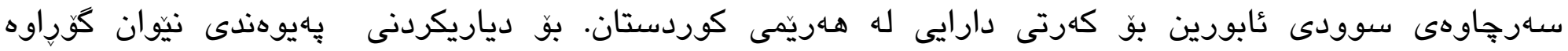

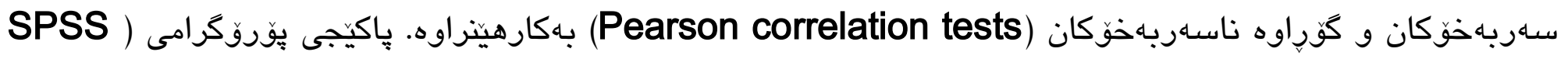

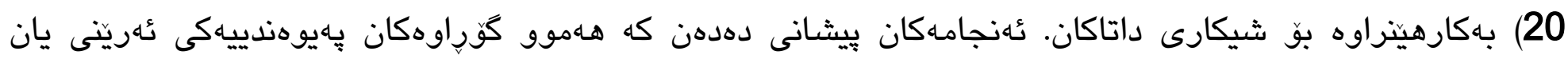

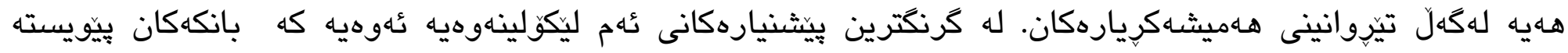

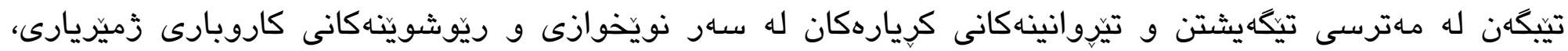

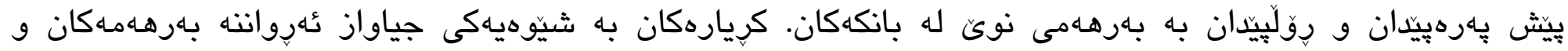

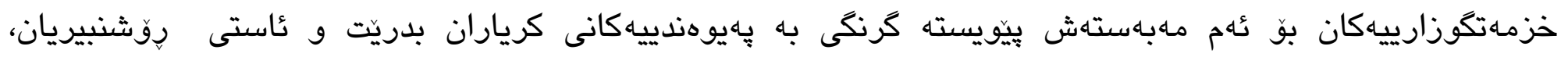
هوَشياريان، و دلّوزَيان باشترو زياتر بكريت.

كليله وشلهكان: نويكهرى، رازيكردنى كرياران، تيجووى مامهلّكان، تواناى بهدستهينان، و دارايى. 


\section{References:}

Abdulsatar A Sultan, Mohammad S A, Ummi N S, Muhammad M Asad, Factors Influencing the Adoption of Mobile Banking Service among Cihan Bank Customers in the Kurdistan Region of Iraq,International Journal of Advanced Science and Technology Vol. 27, No. 1, (2019), pp. 289-301

Abor, J. (2004). Technological innovations and banking in Ghana: An evaluation of customers' perceptions. American Academy of Financial Management, 1, 1-16. [Online] Available: http://www.financialcertified.com/armstrong.html (June 6, 2011)

Ameen, N., \& Willis, R. (2018). An Examination of the Role of National IT Development and Infrastructure in Models for Smartphone Adoption and Use: The Cases of Iraq, Jordan and the UAE Emerging Markets from a Multidisciplinary Perspective (pp. 161-194): Springer.

Ayo CK, Oni,A Adewoye OJ and Eweoya IO(2016), E-banking users behaviour; eservices quality, attitude, and customers satisfaction, international journal of banking marketing vol 34, no3, pp347-367

Baker, K. A. (2002). Organizational communication in Management Benchmark Study/U.S. Office of

Science/Department of Energy, http://www.au.af.mil/au/awc/awcgate/doe/benchmark/(March 25, 2011)

Basel Committee on Banking Supervision, Proposed revisions to the Basel II market risk framework, consultative document, July 2008.

Beckett, A., Hewer, P and Howcroft, B. (2000). An Exposition of Consumer Behaviour in the Financial Services Industry. The International Journal of Bank Marketing, 18(1), p. 15. 
Black, N. J., Lockett, A., Winklhofer, H., \&Ennew, C. (2001). The Adoption of Internet Financial Services: A Qualitative Study. International Journal of Retail and Distribution Management, 29(8), 390-398. https://doi.org/10.1108/09590550110397033

Booz, Allen, and Hamilton Inc. (1982), New Product Management for the 1980s. New York: Booz, Allen, and Hamilton Inc.

CihanBank. (2019). internet-banking. from https://www.cihanbank.com.iq/en/internet-banking/

Crawford, C. Merle (1984), "Protocol: New Tool for Product Innovation," Journal of Product Innovation Management, 1 (2), 85-91.

Crawford, C. $(1987,1997)$. New product management. (2nd Ed. \& 5th Ed.). Illinois: Richard D. Irwin.

Edward Marfo-Yiadom (2012). "Customers' Perception of Innovative Banking Products in Cape Coast Metropolis, Ghana", International Journal of Business and Management

Enotes 2012; Gap Analysis URL:http://www.enotes.com/gap-analysis-reference/gap-analysisCited date 05-01-2012

Eriksson, P. \&Kovalainen, A. (2008). Qualitative Methods in Business Research. s.l.:SAGE Publications

Ernst, H. (2002). Success factors of new product development: a review of the empirical literature. International Journal of Management Reviews, 4, 1-40.

Ezeh, PC, and AN Ezeoke (2013). "Determinant of Adoption Pattern of New Product/Services in Hotel Industry in Awka, Nigeria", African Research Review, 2013.

Gerrard,P and Barton Cunningham, J (2003), "The diffusion of internet banking among Singapore consumers", International journal of banking marketing, Vol 21 No. 1, pp.16-28. https://doi.org/10.1108/02652320310457776 
Hayikader S,Abdhadi FNHB, Ibrahim J (2016), issues and security measures of mobile banking apps,int j sci res oub $2016 ; 6(1): 36$

Jamal, A., Nasser, K. (2002), "Customer satisfaction and retail banking: an assessment of some of the key antecedents of customer satisfaction in retail banking",International Journal of Bank Marketing, No.4, pp.146-60.

Johne, A., \&Snelson, P. (1990). Successful product development. Oxford, UK: Basil Blackwell.

JOSEPH, M. \& STONE, G. (2003) An empirical evaluation of US bank customer perceptions of the impact of technology on service delivery in the banking sector.

Lee, K. C., \& Chung, N. (2009). Understanding factors affecting trust in and satisfaction with mobile banking in Korea: A modified DeLone and McLean's model perspective. Interacting with computers, 21(5-6), 385-392.

Lassar, W., Manolis, C., Lassar, S. (2004). The relationship between consumer innovativeness, personal characteristics, and online banking adoption.

LinhThi Phuong Nguyen, Hieu Vo Chi Tran(2020). "Customer Perception towards Electronic Banking and its Relationship with Customer Satisfaction: An Evidence from Vietnam", International Journal of Business and Management

Mazzucato, M., \&Semieniuk, G. (2017). Public financing of innovation: new questions. Oxford Review of Economic Policy, 33(1), 24-48

Mohammed OOL, Nimzing UN,Uduimoh, N Andrew, Misra,Sanjay 2019, forensic analysis on mobile banking apps $2019 ; 49$

Rogers, E. M. (1995). Diffusion of innovations. New York: The Free Press.

Rogers, E. M. (2003). Elements of diffusion. Diffusion of innovations, New York: The Free Press 351 
Schiffman, L.G., \&Kanuk, L.L. (2009). Consumer behaviour. New Jersey, Pearson Education

Singh, B. and Malhotra P. (2004), 'Adoption of Internet banking: An Empirical Investigation of Indian Banking sector', Journal of Internet Banking and Commerce, Vol. 9, No. 2

Solomon RM (2009). Consumer Behavior: Buying, Having, and Being. (8th ed). UK: Pearson Education 